\title{
Association of vitamin D receptor gene polymorphisms with rheumatoid arthritis
}

\author{
Noelia Márquez Pete ${ }^{1}$, Cristina Pérez Ramírez ${ }^{1,2,3}$, María del Mar Maldonado Montoro ${ }^{4}$, \\ Fernando Martínez Martínez ${ }^{5}$, Fernando Fernández-Llimos², Antonio Sánchez Pozo³ \\ María del Carmen Ramírez Tortosa ${ }^{3}$, Alberto Jiménez Morales ${ }^{1}$
}

\author{
${ }^{1}$ Pharmacy Service, Pharmacogenetics Unit, University Hospital Virgen de las Nieves, \\ UGC Provincial de Farmacia de Granada, Granada, Spain \\ ${ }^{2}$ Department of Social Pharmacy, Faculty of Pharmacy, University of Lisbon, Lisbon, \\ Portugal \\ ${ }^{3}$ Department of Biochemistry, Faculty of Pharmacy, University of Granada, Granada, \\ Spain \\ ${ }^{4}$ Clinical Analysis Service, Hospital Campus de la Salud, Granada, Spain \\ ${ }^{5}$ Department of Physical Chemistry, Faculty of Pharmacy, University of Granada, \\ Granada, Spain
}

Submitted: 2 July 2019

Accepted: 14 January 2020

Arch Med Sci

DOI: https://doi.org/10.5114/aoms.2020.97423

Copyright ( 2020 Termedia \& Banach

\begin{abstract}
Introduction: Rheumatoid arthritis (RA) is a chronic inflammatory autoimmune disease of unknown etiology which causes progressive deterioration of the joints, leading to severe pain and functional disability. Vitamin D and its receptor (VDR) play a significant part in the onset of autoimmune diseases such as RA. The purpose of this study was to evaluate the association between VDR gene polymorphisms and risk of developing RA.

Material and methods: A retrospective study was performed, including 214 RA cases and 748 controls of Caucasian origin. Fokl (rs2228570), Bsml (rs1544410), Taql (rs731236), Apal (rs7975232) and Cdx2 (rs11568820) gene polymorphisms were analyzed by TaqMan.

Results: The recessive logistic regression model showed that the VDR FoklAA genotype was associated with lower risk of RA ( $p=0.0255$; OR $=0.58$; $95 \% \mathrm{Cl}: 0.35-0.92)$. No other genetic polymorphism showed any association with RA in any of the models tested. Haplotype analysis revealed that the haplotypes ACGAG ( $p=0.033$; OR $=1.62 ; 95 \% \mathrm{Cl}: 1.04-2.53)$ and GTGCA $(p<0.01 ; \mathrm{OR}=2.77 ; 95 \% \mathrm{Cl}: 1.53-4.98)$ for Bsml, Cdx2, Fokl, Apal and Taql were associated with higher risk of RA.

Conclusions: VDR Fokl gene polymorphism showed a trend for risk of RA, taking into account the variables of gender, age and tobacco use, and preventing false positives. Among our patients we found no influence of VDR $B s m l, T a q l, A p a l$ and $C d \times 2$ on the risk of developing RA. However, haplotype analysis indicated that the haplotypes ACGAG and GTGCA were associated with higher risk of RA.
\end{abstract}

Key words: rheumatoid arthritis, risk, VDR, polymorphisms.

\section{Introduction}

Rheumatoid arthritis (RA) is a chronic inflammatory autoimmune disease of unknown etiology which causes progressive deterioration of the joints, leading to severe pain and functional disability [1].

\section{Corresponding author:} Cristina Pérez Ramirez PhD Department of Social Pharmacy Faculty of Pharmacy University of Lisbon Av. Prof. Gama Pinto 1600-083 Lisbon, Portugal Phone: +351217946400 E-mail: cperezramirez87@gmail.com 
The global prevalence of RA is calculated to be $0.5-1.0 \%$ of the population, and is two to four times higher in women than in men across all age groups [2]. The etiology of RA is not yet understood, since diverse risk factors of both environmental and genetic origin are involved in its onset and development [3-5]. Smoking is one of the principal factors of environmental risk. Smokers are twice as likely to develop RA, because tobacco increases production of the citrullinated proteins involved in the action mechanism of the disease $[6,7]$. Pollution, stress, diet, and drinking alcohol are also environmental risk factors in RA [8, 9]. Similarly, higher socioeconomic and education levels are associated with a lower risk of RA [10].

Different studies have demonstrated the association between vitamin $D$ and risk of RA. Low vitamin $D$ levels have been associated with higher prevalence of RA [11]. Vitamin D is associated with skeletal metabolism, since it plays a fundamental role in bone mineral homeostasis through its involvement in regulating calcium and phosphate absorption [12]. Vitamin D therefore acts by boosting innate immune processes and reducing the effect of the adaptive immune system, which may lessen the risk of autoimmune diseases such as RA.

One way of studying the role of vitamin $D$ in the immune system as a whole, and in RA in particular, would be to study the proteins and enzymes involved in the action mechanism of RA, such as vitamin $D$ receptor (VDR) and its different polymorphisms $[13,14]$. Vitamin $D$ receptor is a nuclear transcription factor which regulates multiple genes responsible for inflammatory processes and immune system response [15]. The signaling pathway of VDR therefore plays a crucial role in the manifestation of autoimmune diseases. It has been found that different immune system cells express the VDR gene [16]. This expression is found in macrophages, monocytes, and activated $T$ lymphocytes (CD4+, CD8), chondrocytes and synovial cells in the synovial membrane and cartilage in RA patients [16]. In this disease, T lymphocytes, macrophages and activated plasma cells infiltrate joints [17]. Th1 lymphocytes associated with inflammatory processes are involved in the development of the disease, as are proinflammatory cytokines, which leads to the production of TNF-a and the destruction of bone and cartilage [18]. All of this suggests that the VDR gene and its polymorphisms have an effect on disease immune regulation and joint inflammation.

The VDR gene is found on chromosome 12q13.11 and is highly polymorphic [7, 19]. Numerous polymorphisms have been described for this gene, the most widely studied of which are: Fokl (rs2228570, exon 2,+30920 C > T, Met $\rightarrow$ Thr), Bsml (rs1544410, intron 8, +63980 G >A), Taql (rs731236, exon 9, +65058 T > C, lle $\rightarrow$ lle), Apal (rs7975232, intron $8,+64978 C>A$ ) and $C d \times 2$ (rs11568820, exon $1,+1270 \mathrm{G}>\mathrm{A})$. Studies have demonstrated that the different polymorphisms found in the VDR receptor may cause receptor dysfunction and variations in the immune response, and similarly in all of the processes regulated by this receptor. Uitterlinden et al. found that VDR polymorphisms Bsml and Taql created a silent codon which therefore had no effect on the protein structure, but could be associated with greater VDR gene mRNA stability $[20,21]$. As regards the Fokl polymorphism, this is located in the start codon, giving rise to a new initiation site and affecting the structure of the molecule, since there is a change in the size of the synthesized protein which is in the shorter form and has higher transcriptional activity [22]. All of these variations can affect the VDR as regards its structure and function, and therefore also affect vitamin $D$ function as demonstrated in recent studies which have shown that VDR gene polymorphisms are associated with bone loss in RA [21, 23, 24]. Different studies have been undertaken to seek the relationship between the VDR gene and RA, amongst which a meta-analysis was carried out on Caucasian and Asiatic study populations which linked the VDR gene Fokl (rs2228570) polymorphism to the presence of RA in the study population and concluded that low levels of vitamin $D$ may be a risk factor for RA [25]. Another study by Goertz et al. in Germany found a relationship between the Bsml genotype and the occurrence of RA $[14,26]$.

In view of the foregoing, we carried out this study to assess the effects of VDR gene polymorphisms (Fokl (rs2228570), Bsml (rs1544410), Taql (rs731236), Apal (rs7975232) and Cdx2 (rs11568820) on the risk of developing RA.

\section{Material and methods}

\section{Study subjects}

A retrospective case-control study was performed. This study included 214 RA patients and 748 control subjects of Caucasian origin, the case/control ratio being 3. Cases were diagnosed as RA at Virgen de la Nieves University Hospital in Granada, Spain, between 1980 and 2013. Control subjects were Caucasian persons over 18 years old. The subjects participating in this study gave their informed consent in writing for the extraction of blood and saliva samples. This study was conducted in accordance with the Helsinki Declaration and with the approval of the Andalusian Public Health System Biobank Ethics Committee.

\section{Sociodemographic and clinical variables}

Sociodemographic data included gender, tobacco use, age at diagnosis and duration of illness. 
The clinical condition of patients when diagnosed with RA was described using the DAS28 clinical parameter and the RF biochemical parameter. These data were obtained from the hospital databases. Tobacco use was classified into current smokers, former smokers and never smokers. Individuals were classified as never smokers if they had never smoked or smoked < 100 cigarettes in their life; as former smokers if they had smoked $\geq 100$ cigarettes in their life but did not currently smoke, and as current smokers if they had smoked $\geq 100$ cigarettes in their life and still smoked.

\section{Genetic variables}

\section{DNA isolation}

DNA samples isolated from samples of blood or saliva were obtained from the Virgen de la Nieves University Hospital Biobank, which is part of the Andalusian Public Health System Biobank. Blood samples $(3 \mathrm{ml})$ were collected in BD Vacutainer K3E Plus Blood Collection Tubes. Saliva samples were collected in $50 \mathrm{ml}$ conical BD Falcon tubes (BD, Plymouth, United Kingdom). DNA isolation was performed using the QIAamp DNA Mini Kit (Qiagen GmbH, Hilden, Germany) according to the manufacturer's instructions for DNA purification from blood or saliva and stored at $-40^{\circ} \mathrm{C}$.

\section{Detection of gene polymorphisms}

VDR gene Fokl, Bsml, Taql, Apal and Cdx2 polymorphisms were analyzed by real-time PCR using TaqMan probes. The assay ID used for gene Fokl (rs2228570) is C_12060045_20, for $\mathrm{Bsml}$ (rs1544410) is AN324M4, for Taql (rs731236) is C_2404008_10, for Apal (rs7975232) is C_28977635_10 and for Cdx2 (rs11568820) is C_2880808_10. Genotyping analysis was performed using real-time polymerase chain reaction (PCR) allelic discrimination TaqMan genotyping assays (ABI Applied Biosystems, 7300 Real-Time PCR System) based on manufacturer protocols.

\section{Statistical analysis}

Descriptive analysis was performed using R 3.0.1 (27). Quantitative data were expressed as the mean ( \pm standard deviation) for normal-distribution variables or medians and percentiles (25 and 75) for non-normal-distribution variables. The ShapiroWilk test was used to assess normality.

The Hardy-Weinberg equilibrium and frequency of paired haplotypes were determined, and Lewontin's D prime (D') and linkage disequilibrium coefficient $\left(r^{2}\right)$ were calculated. The bivariate correlation between risk of RA and polymorphisms was evaluated for multiple models (genotypic, additive, allelic, dominant and recessive) using Pearson's $\chi^{2}$ test and Fisher's exact test to give the odds ratio (OR) and 95\% confidence interval (C195\%). The models were defined as follows: allelic (D vs. d), dominant ((DD, Dd) vs. dd), recessive (DD vs. (Dd, dd)) and genotypic (DD vs. Dd, Dd vs. dd) and additive, $D$ being the minor allele and $d$ the major allele. Adaptative permutation analysis (EMP1), which compares the observed statistic with 100,000 permutation statistics obtained for the polymorphism in question, was used for multiple comparisons. Unconditional multiple logistic regression models (genotypic, dominant and recessive) were used to determine the influence of possible confounding variables on the risk of RA. All of the tests were bilateral with a significance level of $p<0.05$, and were performed using the free open source R 3.2.2 or PLINK toolset for whole genome association analysis [27-29]. Linkage disequilibrium (LD) was also developed with Haploview 4.2 software and haplotype analysis was performed based on the previous literature with SNPStats, a web tool for the analysis of association studies [30-34].

\section{Results}

\section{Patient characteristics}

The mean age of patients was 45 years $[35,53]$. There were 170 women (170/214, 79.44\%) and 44 men $(44 / 214,20.56 \%)$. The median disease duration was 17 years [11, 22.75], the RF value was above 48 in 108 patients (108/214, 50.47\%) and the DAS28 value was below 5.4 in 110 patients (110/214, 51.4\%). The control group was made up of 342 (45.12\%) women and 416 (54.88\%) men. The median age of control subjects was 64 years $[44,75]$. The clinical, sociodemographic and pathologic characteristics of the 214 RA patients and the 748 control subjects are given in Table I. Cases and controls presented significant differences according to gender $(p<0.01 ; \mathrm{OR}=0.21$; $95 \% \mathrm{Cl}=0.14-0.30 ;$ men vs. women; Table I), age $(p<0.01 ; \mathrm{OR}=2.84 ; 95 \% \mathrm{Cl}=2.08-3.89$; $<45$ years old vs. > 45 years old; Table I) and tobacco use $(p<0.01 ; \mathrm{OR}=5.16 ; 95 \% \mathrm{Cl}=2.78-10.24$; current smokers vs. former smokers and $p<0.01$; $\mathrm{OR}=5.98 ; 95 \% \mathrm{Cl}=3.43-11.31$; non-smokers vs. former smokers; Table I).

\section{Genotype distribution}

Genotype frequencies matched expected values as per the Hardy-Weinberg equilibrium (HWE) model, with the exception of rs1544410 and rs2228570 (Suppl Table I). The D' linkage disequilibrium and $r 2$ values are given in Suppl Table II and Figure 1 shows a graph for LD. All of the polymorphisms presented minor allelic frequencies 
N. Márquez Pete, C. Pérez Ramírez, M. del Mar Maldonado Montoro, F. Martínez Martínez, F. Fernández-Llimos, A. Sánchez Pozo, M. del Carmen Ramírez Tortosa, A. Jiménez Morales

Table I. Clinico-pathologic characteristics of rheumatoid arthritis cases and controls

\begin{tabular}{|c|c|c|c|c|c|c|c|}
\hline Parameter & Cases & Controls & $\chi^{2}$ & $p$-value & Reference & OR & $95 \% \mathrm{Cl}$ \\
\hline \multicolumn{8}{|l|}{ Gender, $n(\%)$} \\
\hline Female & $170(79.44)$ & $342(45.12)$ & 77.48 & $<0.01$ & Female & 0.21 & $0.14-0.30$ \\
\hline Male & $44(20.56)$ & $416(54.88)$ & & & & & \\
\hline Age [years] & $45(35,53)$ & $64(44,75)$ & & & & & \\
\hline$<45$ & $110(51.4)$ & $203(27.14)$ & 43.53 & $<0.01$ & $>45$ & 2.84 & $2.08-3.89$ \\
\hline$>45$ & $104(48.6)$ & $545(72.86)$ & & & & & \\
\hline \multicolumn{8}{|l|}{ Smoking status, $n(\%)$} \\
\hline Current smokers & $50(23.36)$ & $146(20.19)$ & 42.83 & $<0.01$ & & & \\
\hline Former smokers & $13(6.07)$ & $196(27.11)$ & & & & & \\
\hline Non-smokers & $151(70.56)$ & $381(52.70)$ & & & & & \\
\hline Duration of disease [years] & $17(11,22.75)$ & - & & & & & \\
\hline$<17$ & $116(54.21)$ & - & & & & & \\
\hline$>17$ & $98(45.79)$ & - & & & & & \\
\hline RF value & $48(12,121.5)$ & - & & & & & \\
\hline$<48$ & $108(50.47)$ & - & & & & & \\
\hline$>48$ & $106(49.43)$ & - & & & & & \\
\hline DAS28 value & $5.4 \pm 1.16$ & - & & & & & \\
\hline$<5.4$ & $104(48.6)$ & - & & & & & \\
\hline$>5.4$ & $110(51.4)$ & - & & & & & \\
\hline
\end{tabular}

Qualitative variables: number (percentage). Quantitative variables: Normal distribution: mean \pm standard deviation. Non-normal distribution: $P_{50}\left[P_{25}, P_{75}\right]$.

Chr 12 (q13)
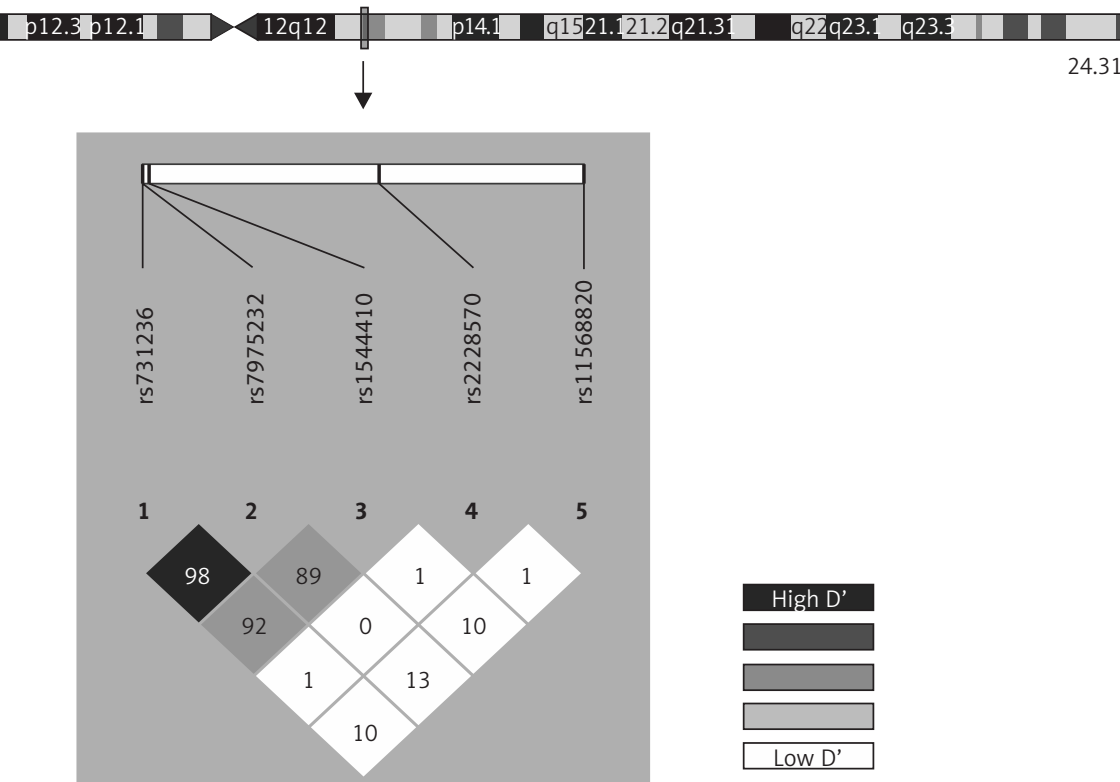

Figure 1. Chromosomal location for VDR, and linkage disequilibrium (LD)

of above $1 \%$ and therefore none of them was excluded from the analysis (Suppl Table III). Haplotype frequency estimations are contained in Suppl Table IV.
Influence of gene polymorphisms on risk of rheumatoid arthritis

Bivariate analysis was carried out on multiple models: genotypic, additive, allelic, dominant and 
recessive (Suppl Table V). VDR Fokl (rs2228570) was the only polymorphism which showed a trend for risk of RA in genotypic and recessive models (Suppl Table V). This trend was also found after correction by permutation analysis (Suppl Table $\mathrm{VI}$ ). The genotypic model showed that patients carrying the AA genotype were at lower risk of RA $(p=0.0613 ; \mathrm{OR}=0.76 ; 95 \% \mathrm{Cl}=0.46-1.23 ; \mathrm{AA}$ vs. GG; Suppl Table VI), whilst carriers of the AG genotype were at risk of RA ( $p=0.0613$; OR $=1.29 ; 95 \%$ $\mathrm{Cl}=0.94-1.80 ;$ AG vs. GG; Suppl Table VI). Similarly, the recessive model showed that patients with the AA genotype were at lower risk of RA compared with patients with the $\mathrm{G}$ allele $(p=0.0980$ $\mathrm{OR}=0.66 ; 95 \% \mathrm{Cl}=0.41-1.03$; Suppl Table VI).

This trend was confirmed in the logistic regression analysis (Table II). The recessive logistic regression model adjusted by gender, age and tobacco use showed that VDR Fokl-AA was associated with a lower risk of RA ( $p=0.0255$; OR $=0.58$; $95 \% \mathrm{Cl}=0.35-0.92$, Table II). No other genetic polymorphism showed an association with RA in any of the models tested. Haplotype analysis adjusted by gender, age and tobacco use revealed that the haplotypes ACGAG ( $p=0.033$; OR $=1.62 ; 95 \%$ $\mathrm{Cl}=1.04-2.53)$ and GTGCA $(p<0.01 ; \mathrm{OR}=2.77$; $95 \% \mathrm{Cl}=1.53-4.98)$ for $B s m l$ ( $r s 1544410), C d \times 2$ (rs11568820), Fokl (rs2228570), Apal (rs7975232) and Taql (rs731236) were associated with higher risk of RA (Table III).

\section{Discussion}

Rheumatoid arthritis is a complex disease in terms of its pathogenesis, since many factors influence its onset and development [35]. However, it has been found to have a significant and complex genetic component that plays a part in both the onset and clinical progression of the disease [35-37]. One of the genes most frequently studied due to its link with autoimmune diseases is the vitamin $D$ receptor gene $(V D R)$, the polymorphisms of which appear to contribute to bone resorption [13]. Rheumatoid arthritis is an autoimmune disease with pronounced inflammatory activity, in which Th1 and Th17 cells are involved, in addition to a high number of cytokines [38]. Different studies have found a relationship between VDR activity and the appearance, differentiation and function of $T$ cells [39]. VDR gene polymorphisms can modify their activity and therefore the biological function of vitamin D, with an effect on the onset and progression of RA $[23,24]$. Low levels of vitamin D can also play a part in disease progression [40]. A study performed on RA patients showed that lower levels of $1,25(\mathrm{OH})_{2} \mathrm{D}$ led to higher disease activity rates, measured using the DAS28 [41].

In terms of susceptibility to RA, the VDR gene Fokl (rs2228570) polymorphism is one of the most

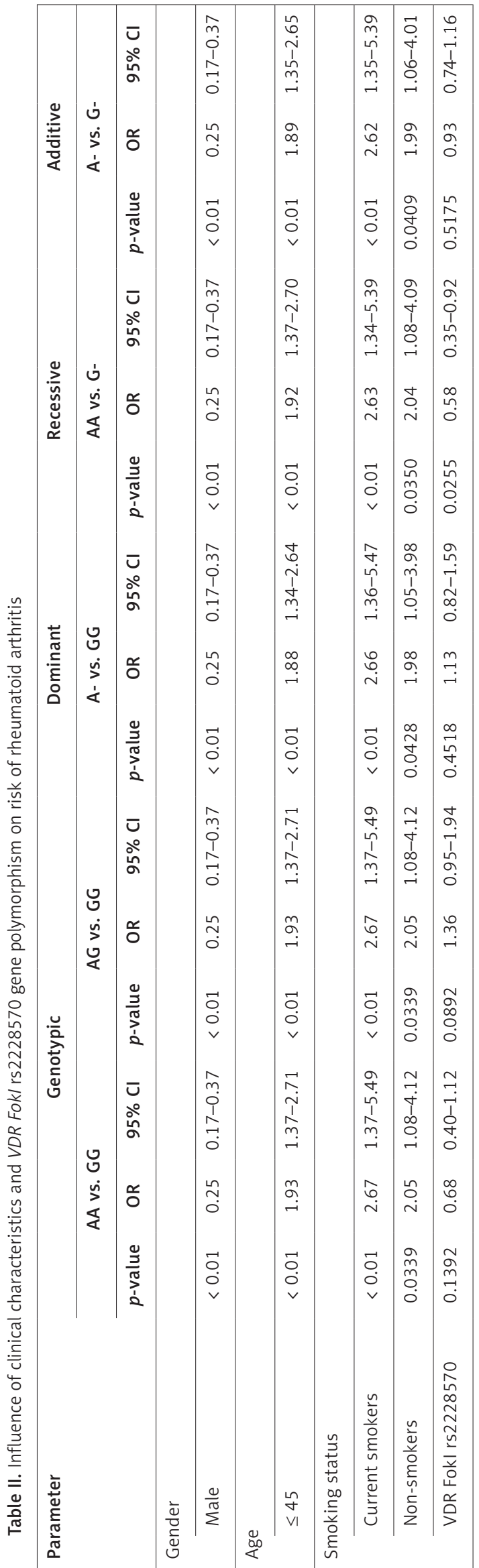


N. Márquez Pete, C. Pérez Ramírez, M. del Mar Maldonado Montoro, F. Martínez Martínez, F. Fernández-Llimos, A. Sánchez Pozo, M. del Carmen Ramírez Tortosa, A. Jiménez Morales

Table III. Haplotype association with response adjusted by gender, age and tobacco use

\begin{tabular}{|c|c|c|c|c|c|c|c|}
\hline Bsml & $\mathrm{Cdx} 2$ & Fokl & Apal & Taql & Freq & OR $(95 \% \mathrm{Cl})$ & $P$-value \\
\hline G & $\mathrm{C}$ & G & $\mathrm{C}$ & A & 0.2155 & 1.00 & - \\
\hline$A$ & C & G & $A$ & G & 0.1815 & $1.62(1.04-2.53)$ & 0.033 \\
\hline G & C & A & C & A & 0.1451 & $1.25(0.77-2.02)$ & 0.370 \\
\hline A & C & A & A & G & 0.0882 & $1.15(0.66-1.99)$ & 0.620 \\
\hline G & $\mathrm{T}$ & G & C & A & 0.0706 & $2.77(1.53-4.98)$ & $<0.01$ \\
\hline A & $\mathrm{T}$ & G & $A$ & G & 0.0577 & $1.31(0.60-2.89)$ & 0.500 \\
\hline G & $\mathrm{C}$ & G & A & A & 0.0564 & $1.03(0.47-2.26)$ & 0.940 \\
\hline A & $\mathrm{T}$ & A & A & G & 0.0518 & $1.20(0.51-2.83)$ & 0.670 \\
\hline G & C & A & A & A & 0.0314 & $1.49(0.62-3.57)$ & 0.380 \\
\hline G & $\mathrm{T}$ & A & C & A & 0.0218 & $0.08(0.00-12826.02)$ & 0.680 \\
\hline G & $\mathrm{T}$ & G & $A$ & $A$ & 0.0175 & $0.74(0.16-3.35)$ & 0.690 \\
\hline G & $\mathrm{T}$ & $A$ & A & $A$ & 0.0133 & $3.02(0.95-9.65)$ & 0.062 \\
\hline * & * & * & * & * & 0.0493 & $0.65(0.30-1.40)$ & 0.270 \\
\hline
\end{tabular}

Global haplotype association p-value: 0.054

widely studied [26, 42-47]. This polymorphism gives rise to a transcription start codon. The Fokl-A variant produces a full (427 aa) vitamin D receptor (VDR), whilst the VDR-Fokl-G variant produces a shorter form of the protein (424 aa) and can increase the risk of developing RA [36]. In our study, the recessive model adjusted by gender, age and tobacco use showed a link between the AA genotype and a lower risk of RA in our patients (Table II), although the genotypic distribution of the Fokl and Bsml polymorphisms in cases and controls does not fulfil the HWE. However, minor allele frequency in our population $(A=0.3271)$ is in consonance with the finding of the 1000 genomes for Iberian population in Spain $(A=0.369)$, so this indicated that we do not have a genotyping error. These results are consistent with a previous meta-analysis of 7 studies carried out on Caucasian and Asiatic populations (1156 cases/1494 controls), which revealed a higher risk of RA among individuals with at least one $\mathrm{G}$ allele of the VDR gene Fokl polymorphism for the allelic model (G vs. A) [48]. In vitro studies have been carried out which show that the short version of the VDR gene protein has high transcriptional activity, which could cause Th1/Th2 imbalance and trigger the RA autoimmune process [44]. Another study by Monticielo et al. showed increased vitamin $D$ levels in patients with the AA genotype compared with patients with the GG genotype [49], matching our results. Another in vitro study found that in GG genotype cells the VDR gene was over-expressed due to an increased transcription rate [50]. This phenomenon could trigger stimu- lation of the RA immune response as a result of the Th1/Th2 imbalance, since VDR has been demonstrated to be involved in the expression of inflammatory and immune response molecules [45].

No significant results were found in our study for the Bsml, Taql and Apal polymorphisms and risk of RA. Bsml and Taq/ polymorphisms are found to be in linkage disequilibrium and are therefore inherited together, whilst Fokl is not associated with any other VDR gene polymorphism and is inherited separately $[45,51]$, which might explain our results. Consistent with our study, a number of previous studies on Caucasian subjects found no association between these polymorphisms and RA [26, 44, 45, 52, 53]. In a study carried out on an Asiatic population, with 130 cases and 146 controls, an association was found between the Bsml polymorphism and risk of RA [13]. A study on lupus erythematosus, also carried out on an Asiatic population, found lower levels of mRNA in patients with the Bsml-G allele $[37,54]$. This leads us to think that geographical location and race are factors that influence the relationship between the VDR gene and development of RA. However, in a meta-analysis of 7 studies with a total of 1152 cases and 880 controls, it was found that the TaqlCC genotype may be a risk factor for RA in Caucasian European subjects [48], which suggests to us that we should increase the sample size of our study in order to improve the results obtained and find a relationship between VDR and RA. The link between VDR gene Apal (rs7975232) polymorphism and risk of RA has been less widely studied. 
A study carried out on an Egyptian population, with 128 cases and 150 controls, found a significant difference between cases and controls as regards frequency of the VDR Apal-CC genotype, which suggests that this genotype may play a part in risk of RA [46].

No other study to date has assessed the link between the VDR Cdx2 polymorphism and RA. We found no significant result in our study as regards this polymorphism. Some studies have described the association of the $C d x 2$ polymorphism with serum levels of vitamin $D$ and the risk of fracture in osteoporosis patients [55]. Consistent with these results, the $C d x 2-C C$ genotype has been identified as a risk factor in bone mineral metabolism and linear growth $[29,56]$.

The main limitation of this study is the small sample size, particularly as regards cases. This may have hindered the detection of associations for some polymorphisms. However, in spite of the limited sample size, and having performed a logistic regression analysis to prevent false positive associations, the effect of the VDR gene Fokl (rs731236) polymorphism on risk of RA persisted. Further studies will be required with a broader range of genetic polymorphisms and a higher number of patients to definitively rule out the influence of these genes on the risk of RA. Among the strengths of our study is the highly homogeneous cohort of cases, since all cases of RA were diagnosed by the same team of rheumatologists and recruited in the same geographical area, which increases uniformity.

In conclusion, VDR Fokl (rs2228570) gene polymorphism showed a trend for risk of RA, taking into account the variables of gender, age and tobacco use, and preventing false positives. Among our patients, VDRBsml (rs1544410), Taql (rs731236), Apal (rs7975232) and $C d \times 2$ (rs11568820) gene polymorphisms were not found to influence the risk of developing RA. However, haplotype analysis indicated that the haplotypes ACGAG and GTGCA were associated with higher risk of RA.

\section{Acknowledgments}

María del Carmen Ramírez Tortosa and Alberto Jiménez Morales contributed equally to the work.

This work was partly supported by a contract for Noelia Márquez Pete from the University of Granada. The Virgen de las Nieves University Hospital Biobank was supported by grants co-funded by ERDF funds (EU) from the Instituto de Salud Carlos III (PT13/0010/0039).

The results of this investigation are part of the doctoral thesis that will be presented by Noelia Márquez Pete in the University of Granada, as part of the doctoral studies in "Clinical Medicine and Public Health".

\section{Conflict of interest}

The authors declare no conflict of interest.

\section{References}

1. Scott DL, Coulton BL, Symmons DPM, Popert AJ. Longterm outcome of treating rheumatoid arthritis: results after 20 years. Lancet 1987; 329: 1108-11.

2. Abdel-Nasser AM, Rasker JJ, Vaikenburg HA. Epidemiological and clinical aspects relating to the variability of rheumatoid arthritis. Semin Arthritis Rheum 1997; 27: 123-40.

3. Bax M, van Heemst J, Huizinga TW, Toes RE. Genetics of rheumatoid arthritis: what have we learned? Immunogenetics 2011; 63: 459-66.

4. MacGregor A, Riste LK, Hazes J, Silman A. Low prevalence of rheumatoid arthritis in black-Caribbeans compared with whites in inner city Manchester. Ann Rheum Dis 1994; 53: 293-7.

5. Lau E, Symmons D, Bankhead C, MacGregor A, Donnan S, Silman A. Low prevalence of rheumatoid arthritis in the urbanized Chinese of Hong Kong. J Rheumatol 1993; 20: 1133-7.

6. Calabresi E, Petrelli F, Bonifacio A, Puxeddu I, Alunno A. One year in review 2018: pathogenesis of rheumatoid arthritis. Clin Exp Rheumatol 2018; 36: 175-84.

7. Liu B, Dong X, Xiao Y, et al. Variability of metabolic risk factors associated with prehypertension in males and females: a cross-sectional study in China. Arch Med Sci 2018; 14: 766-72.

8. Stolt P, Bengtsson C, Nordmark B, et al. Quantification of the influence of cigarette smoking on rheumatoid arthritis: results from a population based case-control study, using incident cases. Ann Rheum Dis 2003; 62: 835-41.

9. Hu Y, Sparks JA, Malspeis S, et al. Long-term dietary quality and risk of developing rheumatoid arthritis in women. Ann Rheum Dis 2017; 76: 1357-64.

10. Millar K, Lloyd SM, McLean JS, et al. Personality, socioeconomic status and inflammation: cross-sectional, population-based study. PLoS One 2013; 8: e58256.

11. Haga HJ, Schmedes A, Naderi Y, Moreno AM, Peen E. Severe deficiency of 25-hydroxyvitamin D3 (25-OH-D3) is associated with high disease activity of rheumatoid arthritis. Clin Rheumatol 2013; 32: 629-33.

12. Puente A, Esposito A, Savastano S, Carpinelli A, Postiglione L, Oriente P. Dietary calcium intake and serum vitamin $D$ are major determinants of bone mass variations in women. A longitudinal study. Aging Clin Exp Res 2002; 14: 382-8.

13. Ranganathan P. Genetics of bone loss in rheumatoid arthritis - role of vitamin $D$ receptor polymorphisms. Rheumatology 2009; 48: 342-6.

14. Będzichowska A, Przekora J, Stapińska-Syniec A, et al. Frequency of infections caused by ESBL-producing bacteria in a pediatric ward-single-center five-year observation. Arch Med Sci 2019; 15: 688-93.

15. Wang TT, Tavera-Mendoza LE, Laperriere D, et al. Largescale in silico and microarray-based identification of direct 1,25-dihydroxyvitamin D3 target genes. Mol Endocrinol 2005; 19: 2685-95.

16. Adorini L, Penna G. Control of autoimmune diseases by the vitamin $D$ endocrine system. Nat Rev Rheumatol 2008; 4: 404-12.

17. Manolagas SC, Werntz DA, Tsoukas CD, Provvedini DM, Vaughan JH. 1, 25-Dihydroxyvitamin D3 receptors in lym- 
phocytes from patients with rheumatoid arthritis. J Labor Clin Med 1986; 108: 596-600.

18. Mclnnes IB, Buckley CD, Isaacs JD. Cytokines in rheumatoid arthritis - shaping the immunological landscape. Nat Rev Rheumatol 2016; 12: 63-8.

19. Miyamoto Kl, Kesterson RA, Yamamoto $\mathrm{H}$, et al. Struc tural organization of the human vitamin $D$ receptor chromosomal gene and its promoter. Mol Endocrinol 1997; 11: 1165-79.

20. Uitterlinden AG, Fang Y, Bergink AP, van Meurs JB, van Leeuwen HP, Pols HA. The role of vitamin D receptor gene polymorphisms in bone biology. Mol Cell Endocrinol 2002; 197: 15-21.

21. Budzyński J, Tojek K, Wustrau B, et al. The "cholesterol paradox" among inpatients-retrospective analysis of medical documentation. Arch Med Sci Atheroscler Dis 2018; 3: e46-e57.

22. Whitfield GK, Remus LS, Jurutka PW, et al. Functionally relevant polymorphisms in the human nuclear vitamin D receptor gene. Mol Cell Endocrinol 2001; 177 145-59.

23. Gough A, Sambrook P, Devlin J, et al. Effect of vitamin D receptor gene alleles on bone loss in early rheumatoid arthritis. J Rheumatol 1998; 25: 864-8.

24. Morrison NA, Yeoman R, Kelly PJ, Eisman JA. Contribution of trans-acting factor alleles to normal physiological variability: vitamin D receptor gene polymorphism and circulating osteocalcin. Proceed Nat Acad Sci 1992; 89: 6665-9.

25. Lee YH, Bae SC, Choi SJ, Ji JD, Song GG. Associations between vitamin $D$ receptor polymorphisms and susceptibility to rheumatoid arthritis and systemic lupus erythematosus: a meta-analysis. Mol Biol Rep 2011; 38 3643-51.

26. Goertz B, Fassbender WJ, Williams JC, et al. Vitamin D receptor genotypes are not associated with rheumatoid arthritis or biochemical parameters of bone turnover in German RA patients. Clin Exp Rheumatol 2003; 21: 333-9.

27. Team RC. R: A language and environment for statistical computing. [Internet]. 2013 Oct. Available from: http:// www.R-project.org/

28. Purcell S, Neale B, Todd-Brown K, et al. PLINK: a toolset for whole-genome association and population-based linkage analysis. Am J Hum Genet 2007; 81: 559-75.

29. Zhai C, Li S, Feng W, et al. Association of interleukin-17a rs2275913 gene polymorphism and asthma risk: a metaanalysis. Arch Med Sci 2018; 14: 1204-11.

30. Sole X, Guino E, Valls J, Iniesta R, Moreno V. SNPStats: a web tool for the analysis of association studies. Bioinformatics 2006; 22: 1928-9.

31. Barrett JC, Fry B, Maller J, Daly MJ. Haploview: analysis and visualization of LD and haplotype maps. Bioinformatics 2005; 21: 263-5.

32. Alyousef YM, Borgio JF, AbdulAzeez S, et al. Association of MBL2 gene polymorphism with dental caries in Saudi children. Caries Res 2017; 51: 12-6.

33. AbdulAzeez S, Al-Nafie AN, Al-Shehri A, et al. Intronic polymorphisms in the CDKN2B-AS1 gene are strongly associated with the risk of myocardial infarction and coronary artery disease in the Saudi population. Int J Mol Sci 2016; 17: 395

34. Asoom LI, Alsuwat HS, Rafique N, et al. Functional DNA variations associated with Saudi female with low VO2max: a pilot microarray study. Am J Transl Res 2019; 11: 3659-70.

35. Boissier MC, Semerano L, Challal S, Saidenberg-Kermanac'h N, Falgarone G. Rheumatoid arthritis: From autoim- munity to synovitis and joint destruction. J Autoimmun 2012; 39: 222-8.

36. Perricone C, Ceccarelli F, Valesini G. An overview on the genetic of rheumatoid arthritis: a never-ending story. Autoimmun Rev 2011; 10: 599-608.

37. Mejias SG, Ramphul K. Prevalence of peripheral arterial disease among diabetic patients in Santo Domingo, Dominican Republic and associated risk factors. Arch Med Sci Atheroscler Dis 2018; 3: e35-40.

38. Annunziato F, Cosmi L, Liotta F, Maggi E, Romagnani S. Type $17 \mathrm{~T}$ helper cells - origins, features and possible roles in rheumatic disease. Nat Rev Rheumatol 2009; 5 : 325-31.

39. Nagpal S, Na S, Rathnachalam R. Noncalcemic actions of vitamin D receptor ligands. Endocrine Rev 2005; 26: 662-87.

40. Shoenfeld N, Amital H, Shoenfeld Y. The effect of melanism and vitamin D synthesis on the incidence of autoimmune disease. Nat Clin Pract Rheumatol 2009; 5: 99-105.

41. Cutolo M, Otsa K, Paolino S, Yprus M, Veldi T, Seriolo B. Vitamin D involvement in rheumatoid arthritis and systemic lupus erythaematosus. Ann Rheum Dis 2009; 68: 446-7.

42. Cavalcanti CA, Silva Jde A, Pita Wde B, et al. Vitamin D receptor polymorphisms and expression profile in rheumatoid arthritis Brazilian patients. Mol Biol Rep 2016; 43 41-51.

43. Hitchon CA, Sun Y, Robinson DB, et al. Vitamin D receptor polymorphism rs2228570 (Fok1) is associated with rheumatoid arthritis in North American natives. J Rheumatol 2012; 39: 1792-7.

44. Karray EF, Ben Dhifallah I, Ben Abdelghani K, et al. Associations of vitamin $D$ receptor gene polymorphisms Fokl and Bsml with susceptibility to rheumatoid arthritis and Behcet's disease in Tunisians. J Bone Spine 2012 79: 144-8.

45. Maalej A, Petit-Teixeira E, Michou L, Rebai A, Cornelis F, Ayadi $\mathrm{H}$. Association study of VDR gene with rheumatoid arthritis in the French population. Genes Immun 2005; 6: 707-11.

46. Mosaad YM, Hammad EM, Fawzy Z, et al. Vitamin D receptor gene polymorphism as possible risk factor in rheumatoid arthritis and rheumatoid related osteoporosis. Hum Immunol 2014; 75: 452-61.

47. Ateş Ö. Vitamin D receptor gene polymorphisms in rheumatoid arthritis. Turkish J Rheumatol 2011; 26: 145-9.

48. Tizaoui K, Hamzaoui K. Association between VDR polymorphisms and rheumatoid arthritis disease: systematic review and updated meta-analysis of case-control studies. Immunobiology 2015; 220: 807-16.

49. Monticielo O, Brenol J, Chies J, et al. The role of Bsm I and Fok I vitamin D receptor gene polymorphisms and serum 25-hydroxyvitamin D in Brazilian patients with systemic lupus erythematosus. Lupus 2012; 21: 43-52.

50. Arai H, Miyamoto KI, Taketani Y, et al. A vitamin D receptor gene polymorphism in the translation initiation codon: effect on protein activity and relation to bone mineral density in Japanese women. J Bone Mineral Res 1997; 12: 915-21.

51. Nejentsev S, Godfrey L, Snook H, et al. Comparative high-resolution analysis of linkage disequilibrium and tag single nucleotide polymorphisms between populations in the vitamin D receptor gene. Hum Mol Genet 2004; 13: 1633-9.

52. Garcia-Lozano JR, Gonzalez-Escribano MF, Valenzuel A, Garcia A, Núñez-Roldán A. Association of vitamin D re- 
ceptor genotypes with early onset rheumatoid arthritis. Eur I Immunogenet 2001; 28: 89-93.

53. Zemtsovskaja G, Abina J, Meigas K, Pilt K, Viigimaa M. Pulse wave velocity and its gender-related associations with cardiovascular risk factors in a high cardiovascular risk population. Arch Med Sci Atheroscler Dis 2018; 3: e99-105.

54. Luo X, Yang M, Wu F, et al. Vitamin D receptor gene Bsml polymorphism $B$ allele, but not BB genotype, is associated with systemic lupus erythematosus in a Han Chinese population. Lupus 2012; 21: 53-9.

55. Ling $\mathrm{Y}$, Lin $\mathrm{H}$, Aleteng $\mathrm{Q}$, et al. Cdx-2 polymorphism in Vitamin $D$ receptor gene was associated with serum 25-hydroxyvitamin D levels, bone mineral density and fracture in middle-aged and elderly Chinese women. Mol Cell Endocrinol 2016; 427: 155-61.

56. Kostik MM, Smirnov AM, Demin GS, Scheplyagina LA, Larionova VI. Juvenile idiopathic arthritis patients and their skeletal status: possible role of vitamin D receptor gene polymorphism. Mol Biol Rep 2014; 41: 1937-43. 